\title{
AUTORI ROMÂNI DE EXPRESIE GERMANĂ
}

\author{
ROMANIAN AUTHORS IN GERMAN
}

\author{
Maria IROD' \\ https://doi.org/10.52744/9786062613242.23
}

\begin{abstract}
Rezumat: Lucrarea prezintă şase autori contemporani de origine română şi expresie germană. Incadrabili în aşa numita literatură a imigranților - categorie distinctă, conturată în studiile literare germane în ultimele patru decenii - cei şase autori au fost selectați după următoarele criterii: limba maternă română, experiența imigrării în spațiul germanofon şi renunțarea la limba maternă în favoarea germanei ca instrument de expresie literară. Pe lângă date bio-bibliografice, lucrarea oferă analize exemplare de text pentru fiecare autor în parte.
\end{abstract}

Cuvinte cheie: Aglaja Veteranyi; Cătălin Dorian Florescu; Carmen-Francesca Banciu; Dana Ranga; Dana Grigorcea; Alexandru Bulucz; Literatură interculturală; Migrație

\begin{abstract}
This chapter presents six contemporary authors of Romanian origin and German expression. Classified as so-called "immigrant literature" - a distinct category outlined in German literary studies in the last four decades - the six authors were selected according to the following criteria: Romanian mother tongue, the experience of immigration in the German-speaking area, and the abandonment of the mother tongue in favor of German. In addition to bio-bibliographic data, the paper provides a representative text analysis for each author.
\end{abstract}

Keywords: Aglaja Veteranyi; Cătălin Dorian Florescu; Carmen-Francesca Banciu; Dana Ranga; Dana Grigorcea; Alexandru Bulucz; Intercultural Literature; Migration

\section{Introducere}

Contactele culturale româno-germane au o tradiție ce merge cel puțin până în secolul al XIX-lea, receptarea literaturii germane în spațiul românesc fiind mediată de autori majori, buni cunoscători ai limbii germane, de la Eminescu până la Lucian Blaga şi reprezentanții Cercului Literar de la Sibiu. Totuşi, cu excepția minoră a lui Iacob Negruzzi care, aflat la studii la Berlin, ține, între 1861 şi 1864, un jurnal în limba germană (Negruzzi 2014), nu există până în ultimele două-trei decenii autori români de expresie germană. Pentru a defini clar obiectul studiului de față, trebuie precizat din capul locului că principalul criteriu de selectare

${ }^{1}$ Conf. dr., Departamentul de Limbi şi Literaturi Germanice al Facultăţii de Limbi şi Literaturi Străine, Universitatea din Bucureşti, maria.irod@lls.unibuc.ro 
a autorilor discutați îl constituie limba maternă română şi adoptarea limbii germane ca limbă de expresie literară. Astfel, este exclusă din start categoria numeroasă şi variată a autorilor de etnie germană (saşi şi şvabi), indiferent dacă aceştia au trăit sau trăiesc în România sau au emigrat în spațiul germanofon, precum şi autorii bi- sau plurilingvi, cu identităţi etno-culturale hibride, dar ancorați în regiuni cu istoric germanofon şi care îşi asumă germana ca limbă maternă: de la celebrul Paul Celan până la contemporanii Carmen Elisabeth Puchianu şi Claudiu M. Florian. În fine, nu sunt luați în considerare nici autori precum Mara-Daria Cojocaru (n. 1980 la Hamburg), care, în ciuda presupuselor rădăcini româneşti, s-au format exclusiv în spațiul germanofon şi a căror operă nu prezintă nicio legătură cu limba şi cultura română. A rezultat, aşadar, în urma aplicării criteriilor de selecție sus-menționate un grup de şase autori care au în comun experiența emigrării la o vârstă mai fragedă sau mai înaintată, optarea conştientă pentru germană ca limbă de expresie artistică şi, bineînțeles, un grad ridicat de interculturalitate, în care imaginile şi trăirile asimilate în România joacă un rol central.

Peisajul literar germanofon a devenit în perioada de după 1945 tot mai permeabil la diversitatea etnică şi culturală, iar fenomenul migrației către R.F.G., Austria şi Elveția - accentuat în perioada de reconstrucție a Germaniei din anii 50-60 şi catalizat de precaritatea economică, tulburările sociale sau de persecuțiile religioase şi politice din Orientul Mijlociu precum şi de regimurile totalitare din Europa de Est - a îmbogățit literatura germană contemporană cu scrieri în care dimensiunea interculturală deține un rol major. Astfel, în ultimele decenii au apărut tot mai multe texte literare în limba germană ai căror autori provin din culturi diferite, cu o altă identitate etnică şi lingvistică, scriitori pe care părăsirea spațiului de origine i-a pus în situația de a adopta limba germană ca instrument al exprimării artistice. Tocmai pentru a susţine şi promova creația unor astfel de exponenți ai reconfigurărilor identitare specifice lumii de astăzi, Fundația Robert Bosch a înființat în 1985 Premiul Adelbert von Chamisso ${ }^{2}$, ce evocă foarte sugestiv începuturile acestui fenomen de transfer lingvistic şi cultural în spațiul german prin numele scriitorului şi naturalistului francez stabilit în Prusia imediat după Revoluția Franceză şi autor al unei opere literare şi ştiinţifice impresionante, redactate exclusiv în limba germană.

Prin lucrarea sa Literatura migrantă în spațiul de limbă germană. Lista Chamisso. Mărirea şi decăderea unui portret de grup (Editura Universității de Vest, Timişoara 2019), Roxana Rogobete întreprinde o cercetare de pionierat ce ia în considerare atât contextul socio-politic al

2 Premiul a fost acordat pentru ultima dată în 2017. 
premiului, cât şi profilul identitar al scriitorilor care l-au primit şi în care îşi găsesc locul şi cei trei laureați de origine română.

Germanistica interculturală - disciplină ce ia avânt în anii 90 în contextul impunerii perspectivei constructiviste asupra identităților colective şi al redefinirii studiilor literare ca studii culturale - grupează sub termenul-umbrelă Migrationsliteratur scrieri literare ale unor autori extrem de diverşi ca origine, profil socio-cultural şi orientare estetică. Din această categorie foarte eterogenă a literaturii imigranților de expresie germană fac parte şi câțiva autori de limbă maternă română bine apreciați pe piața literaturii germanofone contemporane. Dintre aceştia, poate cei mai cunoscuți sunt scriitorii elvețieni de origine română Aglaja Veteranyi (n. 1962, Bucureşti - d. 2002, Zürich) şi Cătălin Dorian Florescu (n. 1968, Timişoara), ambii laureați ai premiului de promovare Adelebert von Chamisso (Veteranyi în 2000 şi Florescu în 2002). De notorietate se bucură însă şi scriitoarea Carmen-Francesca Banciu (n. 1955, Lipova), care a debutat în presa literară din România, s-a stabilit imediat după Revoluție la Berlin şi din 1998 a început să scrie exclusiv în limba germană. În ciuda statutului identitar aparte al autoarei, o modificare similară a identității lingvistice prin abandonarea românei şi adoptarea germanei ca limbă de expresie literară se regăseşte şi în traiectoria poetei şi regizoarei Dana Ranga3 (n. 1964, Bucureşti), stabilită în 1987 în Berlinul de Vest. După un prim volum de versuri în limba română şi mai multe filme documentare foarte apreciate, Ranga şi-a făcut debutul literar german în $2011 \mathrm{cu}$ un volum de poezie publicat direct de prestigioasa editură Suhrkamp, iar în 2014 a primit premiul de promovare Chamisso. Biografia mai tinerei autoare elvețiene Dana Grigorcea (n. 1979, Bucureşti) - care a debutat în 1999 în România literară, iar după diverse stagii de studii şi creație la Bruxelles, Strasbourg şi Bonn, s-a mutat la Zürich şi a publicat în 2011 primul roman în limba germană - este marcată, la scară mai redusă, de acelaşi diacronism identitar. În această privință, scriind inițial în limba maternă şi optând ulterior pentru germană ca limbă de expresie literară, Banciu, Ranga şi Grigorcea se deosebesc atât de Veteranyi şi Florescu, care s-au format în spațiul

\footnotetext{
3 Înclin să-i dau dreptate Roxanei Rogobete care pune sub semnul întrebării pertinența acordării Premiului Chamisso în cazul Danei Ranga, aducând în discuție bilingvismul autoarei şi absența temelor migrației din opera sa. Cf. Roxana Rogobete: Scriitori de origine română în spațiul germanofon (C.D. Forescu, A. Veteranyi, D. Ranga, C.M. Florian). În: Quaestiones Romanicae VI. Canon cultural. Canon literar. Canon lingvistic. Lucrările Colocviului Internațional Comunicare şi cultură în Romània europeană (ediția a VI-a / 16-17 iunie 2016). „Jozsef Attila” Tudomanyi Egyetem Kiado Szeged 2018, p. 263. Totuşi, parcursul biografic al autoarei, experiența părăsirii Bucureştiului natal şi a stabilirii în Germania, debutul în limba română, care îl precedă pe cel în germană, precum şi însăşi acordarea Premiului Chamisso justifică, din punctul meu de vedere, includerea Danei Ranga în studiul de față.
} 
german şi au scris de la început exclusiv în germană, cât şi de cel mai tânăr reprezentant al scriitorilor români germanofoni, poetul Alexandru Bulucz (n. 1987, Alba-Iulia), care şi-a petrecut doar primii treisprezece ani de viață în România, a studiat şi a debutat literar în Germania.

\section{Aglaja Veteranyi}

Aglaja Veteranyi este în multe privințe o voce singulară în literatura germană contemporană. Nu doar marginalitatea socială, caracterul histrionic şi stilul de viață nomad din primii ani ai copilăriei şi adolescenței o disting de ceilalți autori, ci mai ales vocea inconfundabilă, de o puritate poetică absolută, pe care traducătoarea ei, Nora Iuga, o caracterizează ca fiind „ferită de pericolul unei contaminări livreşti prin cultură.” (Chiriac 2012) Fiica unor artişti de circ semi-analfabeți, AglajaVeteranyi s-a născut în 1962 la Bucureşti şi a părăsit țara la vârsta de cinci ani, cutreierând alături de părinții ei țări din Europa, Africa şi America Latină şi apărând ea însăşi în spectacole de circ şi de varieté. În 1977 se stabileşte în Elveția, unde învaţă rapid limba germană şi recuperează anii pierduți de şcoală. În 1982 începe cursuri de actorie la Zürich, oraş în care va trăi ca actriță şi scriitoare liber profesionistă până în 2002, când, măcinată de depresie, îşi va pune capăt vieții. Anii 90 au reprezentat perioada de maximă productivitate a acestei personalități artistice complexe care ajunge să joace un rol important în conturarea curentului neo-avangardist din literatura elvețiană de limbă germană. În 1992, Veteranyi s-a alăturat grupului de tineri autori „Netz”, înființat de Perikles Monioudis şi care atrage şi alți scriitori valoroşi precum Peter Weber şi Ruth Schweikert. Preocupările Aglajei Veteranyi pentru estetica avangardei şi teatrul experimental se concretizează în proiectele de succes inițiate în această perioadă. În 1993 înființează împreună cu René Oberholzer o trupă de teatru axată pe dramatizarea jocurilor de limbaj şi denumită sugestiv „Die Wortpumpe”. Proiectul „Engelsmaschine”5 început în 1996 alături de Jens Nielsen urmăreşte în principal punerea în scenă a textelor dramatice scrise de Veteranyi. Efervescența creatoare şi organizatorică o propulsează pe tânăra autoare cu origini modeste şi parcurs neconvențional în prim planul vieții literare a Elveției germanofone. După apariții ocazionale în presa culturală, urmează debutul editorial cu volumul de versuri Geschenke. Ein Totentanz $(1999)^{6}$ şi, în acelaşi an, romanul care îi va asigura un loc în canonul literaturii germanofone contemporane: Warum das Kind in der Polenta kocht7. Romanul s-a bucurat de un succes imediat fiind desemnat cea mai

\footnotetext{
4 Pompa de cuvinte.

5 Maşinăria îngerilor.

${ }^{6}$ Daruri. Un dans macabru.

7 Deutsche Verlags-Anstalt, Stuttgart 1999. Romanul a fost tradus de Nora Iuga şi a
} 
bună carte a anului 1999 la Zürich şi distins cu Premiul pentru Literatură al oraşului Berlin (2000) şi Premiul de promovare Chamisso (München, 2000). Cartea a fost tradusă în mai multe limbi (spaniolă, română, maghiară, slovacă, franceză, engleză) şi a făcut obiectul mai multor dramatizări şi al unei ecranizări la nivel internațional (Aglaja, 2012; co-producție maghiaro-româno-polonă). Receptarea în România a început destul de timpuriu, inaugurată în chiar anul morții autoarei de traducerea realizată de Nora Iuga, urmată în anul următor de spectacolul lui Radu Afrim de la Teatrul Odeon şi în 2016 de piesa muzicală Aglaja, pe un scenariu de Alina Petrică, în regia lui Ştefan Lupu. Postum au apărut al doilea roman al autoarei, Das Regal der letzten Atemzüge (2002), tradus tot de Nora Iuga sub titlul Raftul cu ultimele suflări ${ }^{8}$, precum şi volumul de proză scurtă Vom geräumten Meer, den gemieteten Socken und Frau Butter $^{9}$ (2004) şi reconstituiri ale fragmentelor rămase nepublicate în manuscris Café Papa, Wörter statt Möbel ${ }^{10}$, Hier Himmel ${ }^{11}$ (toate în 2018). In 2003, Ludwig Metzger a realizat un impresionant portret al autoarei prin filmul de televiziune Hier Himmel - Aglaja Veteranyi, difuzat de 3sat.

Ca multe scrieri literare ale unor autori ce au cunoscut experiența emigrării, cele două romane ale Aglajei Veteranyi au un pronunțat caracter autobiografic. De ce fierbe copilul în mămăligă urmăreşte tribulațiile unei familii de circari fugiți din România lui Ceauşescu, în speranța că se vor îmbogăți şi vor deveni celebri. Textul cu valențe stilistice care îl apropie de un poem în proză relatează, cu vocea naivă a unui copil, spulberarea treptată a acestui vis. În universul îngust al rulotei de circ - imagine exemplară pentru situația paradoxală a dezrădăcinării şi totodată a persistenței unor structuri familiale şi afective osificate - se consumă drame şi abuzuri prezentate direct, fără cosmetizări, de vocea naratoarei. Filtrate însă prin înțelegerea unui copil, aceste detalii sordide sunt purificate de orice urmă de vulgaritate şi se transformă, sub acțiunea limbajului poetic, în imagini de o forță extraordinară. Temele tipice ale literaturii imigranților din Europa de Est - amintirile traumatizante din perioada dictaturii comuniste, şocul cultural la întâlnirea cu Vestul şi deziluziile provocate de contactul dur cu realitățile lumii occidentale sunt prezente şi în această carte, dar ceea ce le conferă singularitate, dincolo de constelația inedită a vieții nomade de circar şi de elementul

apărut în 2002 la Editura Polirom, cu titlul De ce fierbe copilul în mămăligă, fiind reeditat în 2003, 2013 şi 2016.

8 Editura Polirom, Iaşi 2003, reeditat în 2019.

9 Despre marea dereticată, şosetele închiriate şi doamna Untură (traducerea titlului propusă de Rodica Binder, cf. https://arhiva.romlit.ro/index.pl/numarul_37_2004_ro (17.07.2020)).

${ }^{10}$ Cuvinte în loc de mobilă.

${ }^{11}$ Aici cerul. 
carnavalesc inerent acesteia, este stilul lapidar şi consecvent ingenuu, cu pasaje lirice de o frumusețe stranie, aproape onirică, în care cuvintele îşi pierd textura convenţională şi încorporează în formulări frapante suflul vital al povestirii şi emoțiile trezite de ea.

Romanul de relativ mici dimensiuni (sub 200 de pagini, dintre care unele conțin doar o propoziție sau câteva cuvinte) se constituie aşadar ca o relatare la persoana întâi a peregrinărilor şi în final a dezintegrării familiei de circari, văzute din perspectiva unei fetițe ce încearcă să facă față prin limbaj traumelor trăite. Textul redactat la prezent, în fraze scurte și stil preponderent paratactic, creează impresia redării nemijlocite a întâmplărilor, senzațiilor şi trăirilor. Incă din primele pagini aflăm multe detalii despre relațiile dintre personaje şi despre realitățile extraliterare pe fundalul cărora se desfăşoară acțiunea. Ochiurile fine ale plasei narative sunt apte să susțină - într-o întrepătrundere incitantă - experiențe intime şi evenimente relevante pentru contextul istoric, construcții ficționale şi elemente documentare.

Motivul alterității culturale este înscris în chiar structura familiei de circari. Mama - acrobată şi oarecum vedeta trupei datorită numărului ei senzațional în care face jonglerii atârnată de păr de cupola circului - are o identitate multiplă, mereu (de)construită în istorisiri contradictorii: „unsere geschichte klingt bei meiner mutter jeden tag anders [...] Mein Großvater hatte eine Zirkusarena, er war Kaufmann, Kapitän, zog von Land zu Land, verließ nie sein Dorf und war Lokomotivführer. Er war Grieche, Rumäne, Bauer, Türke, Jude, Adliger, Zigeuner, Orthodoxer."12 (p. 57). Identitatea românească şi cea ortodoxă primează însă şi se consolidează prin formulări apodictice: „Rumänische Frauen sind sehr temperamentvoll und sauber, sagt meine Mutter.”13 (p. 40) şi: „Wir sind gute Menschen, sagt meine Mutter, weil wir orthodox sind."14 (p. 37). Tatăl, în schimb, e perceput ca provincial şi străin atât în țara de origine, cât şi în străinătate. Figură ambiguă şi întunecată, clovn cu ambiții ratate de regizor de film, om cu ieşiri violente şi pulsiuni incestuoase, acesta are „o altă limbă maternă decât noi” 15 (p. 50), limbă pe care mama refuză s-o vorbească şi care în percepția copilului sună precum „Speck mit Paprika und Sahne"16 (p. 50). În familia extinsă există şi o soră vitregă cu origini

\footnotetext{
${ }^{12}$ La mama, povestea noastră sună altfel în fiecar ezi. [...] Bunicul avea o arenă de circ, era negustor, căpitan, rătăcea dintr-o țară în alta, nu ieşise niciodată din satul lui şi era mecanic de locomotivă. Era grec, român, țăran, turc, evreu, nobil, țigan, ortodox.

13 Femeile românce sunt foarte temperamentale şi curate, spune mama. (tr. M.I.; în cele ce urmează, traducerea citatelor originale îmi aparţine).

14 Suntem oameni cumsecade fiindcă suntem ortodocşi.

15 Maghiara, deşi acest amănunt nu apare explicit în roman, ci poate fi dedus din aluzii şi din biografia autoarei.

${ }^{16}$ Slănină cu ardei şi smântână.
} 
incerte: „Obwohl sie eine Fremde ist, liebe ich sie wie meine Schwester. Ihre Mutter ist die Stieftochter meines Vaters."17 (p. 22), pe care naratoarea o caracterizează admirativ: „Meine Schwester ist schön wie ein Mann, sie prügelt sich mit allen Kindern. Sie ist eine Zigeunerin."18 (p. 31) şi care face obiectul dorințelor interzise ale tatălui. Mein vater will sowieso nur meine schwester ${ }^{19}$ - conchide naratoarea într-unul dintre acele pasaje scrise cu majusculă, care - o altă marcă stilistică a acestui roman delimitează grafic capitolele şi evidențiază aspecte-cheie ale narațiunii. Împreună cu mama, tata şi cele două surori fuge în străinătate şi o mătuşă, prezentată ca un fel de dublu al figurii materne: meine tante ist wie der schatten meiner mutter ${ }^{20}$, cu rol mai degrabă marginal în circ, dar din ce în ce mai important în viața naratoarei. În microromanul postum Raftul cu ultimele suflări, mătuşa Reta e personajul central, iar agonia şi moartea ei constituie pretextul unui carusel narativ ce reia teme şi motive din De ce fierbe copilul în mămăligăa, reflectate de data aceasta, în orizontul doliului, de conştiinţa unei naratoare mature.

Leitmotivul morții, dominant în Raftul cu ultimele suflări, se regăseşte, în plan secund, şi în primul roman, comprimat într-una din acele aserțiuni aforistice cu majusculă: wir sind viel länger tot als lebendig, deswegen brauchen wir als tote viel mehr glück ${ }^{21}$. (p. 61). Precaritatea existenței resimțită acut de copilul lipsit de siguranța unui cămin stabil se traduce într-o tensiune constantă ce coagulează toate fantasmele şi corespondențele poetice ale naratoarei, în încercarea suprafirească de a birui frica prin cuvinte. Frica este, aşadar, personajul central al romanului, însoțitorul nevăzut şi malefic al oamenilor şi lucrurilor, împotriva căruia naratoarea luptă cu armele limbajului şi ale fabulației. Prin acest motiv recurent al fricii se explică şi titlul romanului: „Während meine Mutter in der Kuppel an den Haaren hängt, erzählt mir meine Schwester das märchen vom kind, das in der polenta kocht, um mich zu beruhigen.”22 (p. 31). Funcția apotropaică a acestui basm absurd, inventat de sora mai mare pentru a alunga frica celei mai mici, devine firul roşu al țesăturii narative şi crește în intensitate odată cu dificultatea situațiilor relatate şi cu nivelul de anxietate al naratoarei care reia, modifică şi extinde povestea după impulsurile de moment.

\footnotetext{
17 Deşi e o străină, o iubesc ca pe sora mea. Mama ei e fiica vitregă a tatei.

18 Sora mea e frumoasă ca un bărbat şi se bate cu toți copiii. E ţigancă.

19 Tata o vrea oricum numai pe sora mea.

${ }^{20}$ Mătuşa mea e ca umbra mamei.

${ }^{21}$ Suntem mult mai mult timp morți decât vii, drept pentru care ca morți avem nevoie de mai mult noroc.

22 În timp ce mama atârnă de păr în cupolă, sora mea îmi spune Povestea cu copilul care fierbe în mămăligă ca să mă liniştească.
} 
Frica generată de condiția emigrantului cu viață nomadă şi trecut dubios - la început toți fugarii se întrețin din banii furați de tată din casieria circului - se împleteşte cu un alt motiv central al romanului, alienarea subiectului depeizat, fără identitate stabilă. Tema pribegiei şi dorului de casă precum şi cea a contrastului între ținutul natal şi lumea vestică sunt abordate inițial prin prisma percepțiilor senzoriale. Copilul asociază țara natală cu mirosul mâncării gătite de mama (p. 10), deşi singurele amintiri vii sunt cele legate de cozile interminabile la alimente (p. 12). Apoi, senzațiile se întrepătrund, mâncarea miroase peste tot la fel, doar dorul de țară îi modifică gustul (p. 12), iar concluzia pe care o trage naratoarea-copil e universalistă şi formulată în stilul specific, frapant-metaforic: străinătatea nu schimbă nimic în esență, peste tot se mănâncă cu gura şi puii tăiați cârâie într-o limbă internațională, înțeleasă de toată lumea (p. 16-17). Pe măsură ce trece timpul, țara natală trezeşte doar emoții negative şi e asociată cu frica. De teama Securității care i-ar putea urmări oriunde, mama le interzice copiilor să le spună străinilor cum îi cheamă (p. 52). Perspectiva narativă a copilului - care integrează firesc, într-un flux epic cu accente suprarealiste, naivități, exagerări şi afirmații generalizatoare reuşeşte să evite clişeele care fie demonizează, fie idealizează Estul şi Vestul, concentrând suma eşecurilor şi deziluziilor în concluzia amarresemnată: „Das Glück hatte ich mir anders vorgestellt.”23 (p. 178).

Elveția apare în acest context ca un spațiu al domesticirii, al civilizării forțate, ostil şi rece în aparență, dar singurul care îi oferă naratoarei şansa de a se exprima. Cele două surori sunt preluate de un cămin de copii cu o atmosferă dominată de austeritatea, frica de diavol şi etica muncii tipice calvinismului. Şcolarizate pentru prima dată, copilele trebuie să învețe alfabetul şi germana în acelaşi timp, ceea ce-i prilejuieşte naratoarei primele reflecții asupra limbajului.

Când mama reuşeşte să-şi recupereze în sfârşit fiica din cămin, părinții sunt deja despărțiti, iar când, în urma unui accident, mama nu mai poate lucra la circ, familia se destramă definitiv. Pentru protagonista de treisprezece ani începe odiseea aparițiilor pe scena cluburilor şi teatrelor de revistă, a trezirii erotice prin experiențe la limita abuzului, pe care naratoarea le transpune în formulări perifrastice de o expresivitate cu atât mai şocantă. O îmbolnăvire subită, cu valoare simbolică, o erupție care îi maculează frumusețea puberală, conjugate cu pierderea vocii, pune capăt abrupt carierei incipiente în lumea varieté-ului. Revenită în Elveția, sub ocrotirea mătuşii, naratoarea reia şcoala şi înregistrează un nou eşec atunci când comisia de admitere a unei şcoli de actorie o respinge pe motiv că s-a prezentat ca la circ (p. 187).

23 Îmi imaginasem altfel fericirea. 
Finalul romanului apare ca o viziune în care realul se îmbină cu fantasticul. În această secvență cu accente onirice tatăl apare în fracul lui preferat, în postură de director de circ, rol ce se suprapune cu imaginea lui Dumnezeu. În filmul regizat de tatăl din vis, Dumnezeu e un străin melancolic aflat mereu în pribegie, care-şi aprofundează tristețea cântând la vioară cântece ungureşti şi mâncând mămăligă, din solidaritate cu oamenii săraci (p. 186-9).

Aşa cum s-a observant adesea în studiile dedicate Aglajei Veteranyi, scriitura ei este profund marcată de alegerea germanei ca limbă de expresie artistică, „deteritorializare” ce o apropie pe autoare de situația descrisă de Deleuze şi Guattari prin conceptul de „literatură minoră”. Laura Gieser analizează fenomenul tranziției de la limba maternă la limba de adopție pe două paliere (Gieser 2006). La nivel psihologic şi social, despărțirea de limba maternă echivalează cu tăierea cordonului ombilical şi cu emanciparea față de mediul anti-cultural al familiei. Adoptarea germanei literare în contextul Elveției multilingvistice, unde spațiul germanofon însuşi este scindat între dialectul vorbit şi forma oficială a limbii scrise, subliniază caracterul convențional al limbajului, fără legături organice cu etnicitatea, şi totodată voința autoarei de a se asimila culturii majoritare şi de a se servi de o lingua franca suficient de neutră şi artificială, încât să-i dea sentimentul de distanță estetică față de propria viață. La nivel stilistic, prezența nevăzută a limbii române modulează textul german prin exorbitare retorică şi obținerea unor efecte de originalitate prin traducerea expresiilor idiomatice româneşti.

\section{Cătălin Dorian Florescu}

Din teme similare - contrastul dintre Est şi Vest, evadarea din totalitarism, dramele familiale, dar mai ales condiția emigrantului sub forme dintre cele mai diverse, destinul omului care pleacă de acasă în căutarea necunoscutului - se hrăneşte şi substanța epică a romanelor lui Cătălin Dorian Florescu. Spre deosebire de stilul minimalist şi experimental din proza Aglajei Veteranyi, romanele lui Florescu au o mai mare densitate narativă, o întindere mai amplă şi sunt adesea concepute ca o saga ce cuprinde istoria de viață a oamenilor din mai multe generații.

Născut în 1967 la Timişoara, Cătălin Dorian Florescu a crescut într-o familie care i-a cultivat de mic pasiunea lecturii. După o primă tentativă eşuată de stabilire în Vest, familia Florescu emigrează în Elveția în 1982, la scurtă vreme după ce fiul adolescent intră la liceu. Aventurile emigrării fac obiectul primului său roman, Wunderzeit (2001)24, care a marcat debutul unei cariere literare de succes. Stabilit la Zürich, Cătălin Dorian Florescu a studiat psihologia, s-a specializat în terapia gestaltistă şi a

24 Vremea minunilor, traducere de Mariana Bărbulescu, Editura Polirom, Iaşi 2005. 
lucrat într-un centru de reabilitare a dependenților de droguri până în 2001, când a devenit scriitor liber profesionist. Este autorul a şase romane şi al unui volum de proză scurtă, toate cărțile fiind traduse prompt în limba română de Mariana Bărbulescu şi publicate la editurile Polirom şi Humanitas 25 . Recunoaşterea în spațiul german n-a întârziat să apară, Florescu fiind laureatul unor premii de prestigiu şi beneficiind de burse şi rezidențe literare care i-au înlesnit în ultimii ani o susținută muncă de documentare şi creație. Printre cele mai importante distincții se numără Premiul de promovare Chamisso în 2002, Premiul Anna Seghers în 2003, rezidența literară la Dresda (2008), Cartea anului în Elveția (2011, pentru Jacob se hotărăşte să iubească), Premiul Eichendorff (2012) şi Premiul Andreas Gryphius pentru întreaga activitate literară (2018). Din 2013 Cătălin Dorian Florescu este membru corespondent al Academiei Bavareze de Arte Frumoase.

După cum mărturiseşte adesea în interviuri, autorul situează imboldul originar al propriei literaturi în plăcerea genuină de a povesti, dorință absolut naturală pe care o împarte „cu mii de alți oameni care fac acest lucru, mulți scriitori celebri şi mulți anonimi care nici nu ştiu să scrie.”26 Chestionat asupra relației dintre limba maternă şi limba în care scrie literatură, Florescu spune că alegerea s-a petrecut natural - „ar fi fost ciudat să stau în Zürich şi să scriu în română” - şi că „ambele limbi sunt sudate în identitatea mea fără să se opună una alteia." 27 Pe de altă parte, limba română şi originea est-europeană sunt mai mult decât reminiscențe ale copilăriei şi ingrediente exotice care-l includ pe autor în categoria eteroclită a literaturii imigranților. Dincolo de reticența lui Florescu de a se lăsa etichetat şi de faptul că subliniază în repetate rânduri universalitatea temelor sale - impasul existențial, frica şi disperarea, lupta pentru supraviețuire şi căutarea fericirii - scriitorul îşi exploatează estetic bilingvismul şi rădăcinile româneşti, producând o literatură „de tip german”, dar care „are un alt spirit, un alt suflu, o ființă care vine de

25 Romanul de debut a fost urmat de romanele Der kurze Weg nach Hause. Pendo, Zürich 2002 (Drumul scurt spre casă. Editura Polirom, Iaşi 2006), Der blinde Masseur. Pendo, Zürich 2006 (Maseurulorb. Editura Polirom, Iaşi 2007), Zaira. Editura C.H. Beck, München, 2008 (Zaira. Editura Polirom, Iaşi, 2010), Jacob beschließt zu lieben. Editura C.H. Beck, München 2011 (Jacob se hotărăşte să iubească. Editura Polirom, Iaşi 2012), Der Mann, der das Glück bringt. Editura C.H. Beck, München 2016 (Bărbatul care aduce fericirea. Editura Humanitas, Bucureşti 2018) şi de volumul de povestiri Der Nabel der Welt. Editura C.H.Beck, München 2017 (În buricul pământului. Editura Humanitas Bucureşti 2019).

26 Interviu cu Sorin Şerb: https://romania.europalibera.org/a/30037 310.html (20.07.2020).

27 Interviucu Codruța Simina: https://pressone.ro/catalin-dorian-florescu-scriitorpojghita-de-civilizatie-este-foarte-subtire-peste-tot-are-fisuri-nu-doar-in-est-ci-si-invest (20.07.2020). 
altundeva, din spațiul latin"28. Un pasaj dintr-un interviu acordat revistei Observator cultural descrie pregnant statutul intercultural al scrierilor lui Florescu şi importanța alimentării acestora din rezervorul imaginarului cultural românesc:

Trăiesc într-o lume rațională, corectă, punctuală, de prestări servicii, de străzi trase parcă cu rigla şi bine îngrijite, o lume a unui capitalism superdezvoltat, dar care a scos din funcție poezia, magia, misterul, legenda, orice dramatism şi iritație. Este deseori o viață în surdină. O frază precum cea de la începutul romanului Jacob se hotărăşte să iubească: „In orice furtună se ascunde un diavol" ar fi cu totul deplasată şi lipsită de credibilitate dacă s-ar referi la o realitate elvețiană. De aceea, folosesc uneori arhaisme. Pentru a scăpa de această aplatizare şi pentru a da poveştii rădăcini şi o profunzime suplimentară. Cultura estică încă mai are rădăcini în viața arhaică a satului, a superstiției, de exemplu, şi dacă vrei să o descrii, nu ai voie să le uiți. În cultura vestică însă, aceste rădăcini au putrezit de mult. De aceea sînt aşa de fericit de-a avea România ca pămînt fertil al imaginației mele. ${ }^{29}$

Cel mai recent roman al lui Florescu, Bărbatul care aduce fericirea, poate fi considerat exemplar pentru arta narativă a autorului. O primă caracteristică evidentă este componenta accentuat documentară ce concentrează în paginile cărții detalii sociale şi istorice de pe două continente şi desfăşurate pe parcursul a peste un secol. Această dimensiune realistă care prețuieşte creionarea atentă a fundalului istoric se regăseşte în toate cărțile lui Florescu şi dă consistență dramelor umane şi veridicitate evoluției psihologice a pesonajelor. Dacă pentru Jacob se hotărăşte să iubească, roman care reconstituie - pornind de la poveştile de viață a două generații reprezentate de Jakob (tatăl) şi Jacob (fiul), întinse din anii 20 până în perioada stalinistă - toată istoria colonizării Banatului de către şvabi, autorul a avut nevoie doar de material de arhivă şi de câteva „călătorii în Alsacia şi Lorena, precum şi în satele bănățene fondate de coloniştii veniţi din acele regiuni franceze"3o, documentarea pentru următorul roman a fost mult mai laborioasă. Bărbatul care aduce fericirea pune față în față doi naratori din lumi foarte diferite - un bărbat din New York şi o femeie din Tulcea - care îşi spun unul altuia poveştile marcate de tragedii, zbucium şi speranță ale propriilor înaintaşi. Problematica întrepătrunderii dintre memoria individuală şi cea colectivă, a sedimentării în straturile conştiinței moderne a experienței generațiilor anterioare, este comună ultimelor trei romane: Zaira, Jacob

28 Ibid.

29 Interviu cu Doina Ioanid: https://www.observatorcultural.ro/articol/sint-asa-defericit-de-a-avea-romania-ca-pamint-fertil-al-imaginatiei-mele/ (20.07.2020).

3o Ibid. 
se hotărăşte să iubească şi Bărbatul care aduce fericirea. În cazul celui din urmă reapare motivul visului american, present şi în Zaira, ce prilejuieşte o privire panoramică asupra oraşului New York, începând cu constituirea ghetourilor de imigranți, la sfârşitul secolului al XIX-lea, şi până la tragedia prăbuşirii turnurilor gemene la 11.09.2001.

Aşadar, două personaje, care se întâlnesc întâmplător într-un mic varieté new-yorkez în ziua atentatului de la World Trade Center, îşi povestesc istoria de familie începând cu bunicii. Elena, o muncitoare cu fire înăsprită de greutățile vieții, a venit la New York cu intenția de a împrăştia cenuşa mamei pe pământ american, convinsă că asta şi-ar fi dorit femeia simplă care i-a dat naştere în leprozeria de la Tichileşti şi pe care boala timpurie a împiedicat-o să-şi îndeplinească visul de a-şi căuta norocul peste ocean. În felul său, Ray, artistul de vodevil care s-a specializat în imitarea cântăreților celebri, împlineşte şi el postum visul bunicului, poreclit „micul Caruso”, pe care împrejurările vitrege nu l-au lăsat să-şi valorifice talentul muzical. Vocile celor doi naratori se intersectează abia în capitolul 7 , până atunci identitățile lor rămân în umbră lăsând în prim plan poveşti din generațiile anterioare care-l poartă pe cititor de pe coasta de est a Americii anilor 1900 până în Delta Dunării din primele decenii ale secolului XX. În prima jumătate a romanului, cu greu se poate stabili o conexiune între firele epice, care se derulează alternativ, formulate într-un stil oarecum impersonal de naratori care-şi fac simțită prezența foarte discret prin scurte comentarii, adresări directe şi prolepse. Povestea adolescentului fără adăpost care vinde ziare şi lustruieşte pantofi pe străzile New York-ului în anii 1890, luptându-se cu foamea, frigul şi pericolele metropolei, este exemplară pentru un anumit spirit libertarian şi hedonist al Americii, dar şi, la un nivel mai general, pentru condiția umană pendulând între instinctul egoist de afirmare a sinelui şi nevoia de iluzionare în căutarea disperată a fericirii. Identitatea multiplă şi imposibil de circumscris a tânărului care nu-şi cunoaşte părinții şi care adoptă în funcție de circumstanțe un nume irlandez, italian sau evreiesc, încercând să supraviețuiască în lumea dură a ghetourilor de imigranți, vorbeşte nu doar despre melanjul identitar ce constituie fundamentul Statelor Unite, ci şi despre fluidizarea realităţilor etno-culturale în lumea globalizată. De cealaltă parte, universul aproape atemporal al Deltei Dunării în care oamenii trăiesc în acord cu ritmurile naturii şi se orientează după superstiții străvechi poartă la rândul său o amprentă multiculturală - diversitatea etnică a regiunii, mediul cosmopolit al portului Sulina - în care se insinuează treptat modernitatea, prin ştirile din ziar şi mesajele de la cei plecați departe, trezind dorul de aventură al celor rămaşi. Incă înainte de a le întrezări conexiunile în economia romanului, între poveştile de familie ale naratorilor se țes corespondențe 
bazate pe imagini recurente ce constituie leitmotive ale întregii desfăşurări narative. Tema naşterii, aflate mereu în proximitatea morţii, a vieții triumfătoare şi caduce, în permanență amenințate de pieire, este cadrul în care se regăsesc istoria Elenei din satul pierdut între ape, aproape de vărsarea Dunării în mare - bunica naratoarei care, după ce naşte mai mulți copii morți, reuşește, descântată de vrăjitoarea Deltei, să-şi îndeplinească misiunea vieții, aducând-o pe lume pe a doua Elenă - şi cea a pribeagului american care, pentru a supraviețui, acceptă să participe la uciderea unor copii nedoriți. Casa cu fete gravide într-un bloc părăsit din New York, unde „bărbatul care aduce fericirea” le emoționează pe locatare până la lacrimi cu cântecele sale, şi imaginea acestuia odihnindu-se apoi, anonim cameleonic, la pieptul unor femei de origini diferite, care-l hrănesc cu laptele lor secretat în exces, sunt metafore puternice ale ciclului existenței, unde naşterea şi moartea sunt fețe ale aceluiaşi proces natural. Prin semnificațiile simbolice ale apei, inserate în ambele poveşti paralele, se realizează încă o conexiune între destinele personajelor, la nivelul marilor teme literare. Apa - simbol al regenerării şi fluxului vital, dar şi cale de acces spre tărâmul morților - e prezentă în ambele lumi, evocând forța eternă și amorală a naturii. La New York, morții săraci sunt duşi cu un vapor (o luntre a lui Charon) pe o insulă, unde diferențele culturale sunt şterse definitiv în moarte. La celălalt capăt al lumii, pescarul Vanea, simțindu-şi sfârşitul aproape, se refugiază departe de oameni, trăieşte o vreme pe plauri alături de păsările şi animalele locului, iar moartea lui e o reîntoarcere în circuitul naturii, o dispariție totală, lipsită de rituri funerare. În fine, un alt pilon pe care se sprijină construcția romanului este motivul povestirii cu efect apotropaic, fir roşu care străbate narațiunea, dar şi o posibilă sugestie autoreflexivă valabilă pentru întreaga artă narativă a lui Florescu. În clipele de criză, adolescentul aflat la limita subzistenței îşi roagă prietenul să-şi povestească viaţa şi are, la rândul său, puterea de a-şi fermeca semenii cu ficțiuni puse pe muzică. La Sulina oamenii sunt avizi să afle ce se întâmplă în lumea largă şi să uite de propria viață ternă, aşa că marinarii cu talent la povestit beau şi mănâncă pe banii localnicilor veniți să-i asculte.

Magia fabulatorie ca şansă a ridicării deasupra unui cotidian tern şi ostil joacă, de altfel, un rol esențial în arta poetică a lui Cătălin Dorian Florescu şi îi traversează, sub diferite forme, toate cărțile. În contextul literaturii germanofone de astăzi, proza autorului elvețian de origine română se încadrează, aşadar, în curentul tot mai popular al reabilitării epicului pur şi al impulsului primar de a povesti. 


\section{Carmen-Francesca Banciu}

Temele clasice ale literaturii imigranților - întâlnirea dintre Est şi Vest, bagajul inevitabil de experiențe şi emoții trăite în țara de origine, relația complicată dintre specific şi universal - grefate pe un consistent suport autobiografic se regăsesc şi în literatura scrisă de CarmenFrancesca Banciu. Spre deosebire de Florescu şi Veteranyi, Banciu plasează moştenirea dictaturii comuniste în centrul atenției, astfel încât personajele din cărțile ei acționează pe fundalul istoriei recente a României şi romanele capătă o dimensiune documentară importantă. Tema eliberării individului de constrângerile unui regim opresiv şi a reinventării de sine într-un nou context socio-politic este prin urmare o constantă a literaturii autoarei, un fir roşu ce traversează o țesătură de teme general-umane: iubirea şi moartea, decăderea fizică, relațiile dintre părinţi şi copii. La nivel stilistic, scriitura practicată de Carmen-Francesca Banciu se distinge prin frazele scurte, sacadate, cu exprimări eliptice, prin prezența anacolutului, a stilului indirect liber şi prin alternanța narațiunii la persoana întâi şi a relatării la persoana a treia.

Născută în 1955 la Lipova, județul Arad, ca fiică a unui demnitar comunist, Carmen-Francesca Banciu urmează studii de pictură bisericească la Arad, apoi, la Bucureşti, o şcoală postliceală de secretariat şi comerț exterior. Frecventează Cenaclul de Luni şi debutează editorial cu volumul de proză scurtă Manual de întrebări, publicat de editura Cartea Românească în 1984 şi bine primit de critica literară a vremii. În anul următor, participă cu o povestire tradusă de Rolf Bossert31 la un concurs internațional de proză scurtă organizat în oraşul Arnsberg din Renania de NordWestfalia. Premiul obținut la acest concurs i-a atras tinerei autoare interdicţia de a publica în România. Imediat după schimbarea de regim din 1989, Banciu îşi reia activitatea literară, devenind, printre altele, redactor şi membru fondator al revistei Contrapunct. În 1991 ajunge la Berlin, cu o bursă de tip Artist-in-Residence din partea DAAD32. De atunci, CarmenFrancesca Banciu trăieşte în capitala Germaniei ca autoare liber-profesionistă, desfăşurând în paralel o susținută activitate jurnalistică şi predând cursuri de creative writing la diferite universități și instituții culturale, atât în Germania, cât şi în străinătate. După debutul din România, i-au apărut volumele Fenster in Flammen (1992), Filuteks Handbuch der Fragen (1995), O zi fără preşedinte (1998), Vaterflucht (1998), Ein Land voller Helden (2000), Berlin ist mein Paris (2002), Das Lied der traurigen Mutter (2007), Leichter Wind im Paradies (2015), Lebt wohl, Ihr Genossen und Geliebten (2018). Dacă primele două volume au fost traduse

${ }^{31}$ Rolf Bossert (1952, Reşița - 1986, Frankfurt am Main) = poet german, membru al Grupului de Acțiune Banat.

32 Serviciul German de Schimb Interacademic. 
din limba română de traducători consacrați33, iar cel de-al treilea a fost publicat în România la Editura Fundației Culturale Române, romanul Vaterflucht 34 reprezintă debutul german al autoarei şi totodată primul volum dintr-o trilogie autobiografică din care mai fac parte Das Lied der traurigen Mutter35şi Lebt wohl, Ihr Genossen und Geliebten ${ }^{36}$, nominalizat la Deutscher Buchpreis 37 pe anul 2018. Carmen-Francesca Banciu a beneficiat de mai multe burse de creație, printre care cea acordată de Wissenschaftskolleg zu Berlin, şi a fost „Craig-Kade Writer in Residence” la Rutgers University, în Statele Unite ale Americii. Trei romane şi alte câteva texte mai scurte i-au fost traduse în limba engleză şi receptarea operei sale în spațiul anglo-saxon este favorizată de turneele de lectură publică, de workshop-urile de scriere creativă susținute la universități din S.U.A. şi Marea Britanie şi de proiecte precum Testimony in Practice: Working with Stories of the Self and Others, derulat la Birmingham în 201938.

Dintre toți autorii români de limbă germană, Carmen-Francesca Banciu scrie poate literatura cu cea mai pronunțată dimensiune politică. După cum mărturiseşte adesea în interviuri, atmosfera opresivă din familie - „Am fost crescută în ideea de a devein omul nou al unei noi ere.”39 - şi rebeliunea împotriva acesteia i-au modelat de timpuriu scala de valori şi, implicit, temele majore care îi subîntind scrierile literare. Dacă trilogia autobiografică lămureşte constituirea subiectivității personajului narator, Maria-Maria, alter ego al autoarei, prin opoziție cu restricțiile impuse de regimul totalitar şi revendicarea libertății de exprimare ca valoare fundamentală, romanele $O$ zi fără președinte şi varianta rescrisă în

33 Ferestre în flăcări, prima carte publicată în Germania, la Rotbuch Verlag din Berlin, însumează povestiri mai vechi, din perioada bucureşteană, şi mai noi, din cea berlineză, traduse în germană de Rolf Bossert şi Ernest Wichner. Cea de-a doua carte, Manualul întrebărilor lui Filutek, reia textele din volumul de debut, în varianta germană a lui Georg Aescht.

34 Fuga de tată, apărut la Berlin, la Editura Volk\&Welt.

35 Cântecul mamei triste, roman apărut la Berlin, la Rotbuch Verlag. Fragmente din această carte au apărut în presa culturală din România, în traducerea autoarei.

${ }^{36}$ Adio, tovarăşi şi iubite! Apărut la Editura germanofonă şi anglofonă PalmArtPress din Berlin.

37 Premiu acordat anual (începând cu 2005) de Börsenverein des Deutschen Buchhandels (Asociația editorilor şi librarilor germani), în deschiderea Târgului de Carte de la Frankfurt, pentru cel mai bun roman al anului, scris în limba germană.

${ }_{38}$ Proiectul inițiat de Sara Jones a presupus, printre altele, prezentarea unei versiuni dramatizate a romanului $O$ țară plină de eroi. Sub titlul $A$ Land Full of Heroes, piesa prezentată în cadrul festivalului Birmingham European aduce pe scenă două personaje întruchipate de însăşi Carmen-Francesca Banciu şi de fiica acesteia, actrița Meda Gheorghiu Banciu.

39 Interviucu Ana-Maria Mandra. http://levurelitteraire.com/carmen-francesca-banciuinterview-roumain/ (25.07.2020). 
germană Ein Land voller Helden 40 analizează „ce se petrece cu indivizii şi cu societatea în urma unei implozii. Şi explozii în acelaşi timp. Criza societății şi criza individului. Sau redescoperirea individului după colapsul unei societăți bazate pe ideea de comunitate." ${ }^{4}$

Oțară plină de eroi aduce în prim plan ruptura de paradigmă indusă de momentul epocal al prăbuşirii regimului comunist şi efectele acesteia în planul subiectivității, al crizelor interioare şi derivei axiologice resimțite de indivizii ce trăiesc autoreflexiv mari evenimente istorice. Romanul este scris din perspectiva tânărului jurnalist Radu Iosif care, obsedat de „ziua aceea”, de „momentul zero şi eroii săi ascunşi” (Banciu 2019, 13), porneşte pe cont propriu o anchetă, încercând să-şi răspundă la întrebarea: „A fost kitsch, puci, război civil sau revoluție?” (Banciu 2019, 14) În economia romanului, acest narator-martor ocupă o poziție asumat neutră față de evenimentele la care nu a participat, dar pe care încearcă să le reconstituie discutând cu participanți direcți, consemnându-le relatările şi reflecţiile şi integrând vocile acestora în fluxul narativ. Cele 51 de capitole scurte, numerotate simplu „unu”, „doi” etc., urmăresc destinele a nouă prieteni - Maria-Maria, Ilina, Valer, Varvara şi Artur Ionescu, Maxim Apostolescu, Sandra, Augustin şi Toma, cel mort în timpul evenimentelor şi, prin urmare, singurul „erou” în sensul strict al termenului - tineri intelectuali ce rezistă abuzurilor unui regim dictatorial, uniți în nevoia comună de adevăr şi libertate. Răsturnările abrupte intervenite în societate după acest punct de cotitură din istoria recentă le bulversează existențele, spulberă solidaritatea de grup nutrită de revolta față de un duşman comun şi catalizează în fiecare un dureros proces de reconfigurare a propriei identități. Pornind de la întrebările tăioase ale naratorului-reporter, concentrate inițial asupra zilelor tulburi din decembrie 1989, relatările personajelor se întretaie şi se dezvoltă anarhic, urmează meandrele memoriei şi volutele interpretărilor adeseori contradictorii, ajungând să recreeze un tablou complex al societății româneşti în comunism. Ambivalența morală, întrepătrunderea dintre planul politic şi cel privat, dintre ideologia ce mutilează realitatea şi structurile osificate care reglementează relațiile dintre oameni se reflectă în constelații familiale precum cea a lui Artur Ionescu, unde conflictul între generații, trădarea şi politicul nu pot fi disociate. Tatăl lui Artur e un activist de partid care trăieşte o inflație a ego-ului alimentată de discursul moralist-propagandistic despre „omul nou”, rămânând totodată prizonierul unei viziuni patriarhale despre familie. Îşi forțează fiul adolescent să

40 Cartea a apărut în traducerea Anei Mureşanu sub titlul $O$ țară plină de eroi, Editura Tracus Arte, Bucureşti 2019.

${ }^{41} \mathrm{http}: / /$ levurelitteraire.com/carmen-francesca-banciu-interview-roumain/ (12.07.2020). 
mănânce - reproşându-i că nu vrea să se maturizeze: „Ăsta nu vrea să crească.[...] Să devină adult. Fuge de responsabilitate.” (Banciu 2019, 168-169) şi asociind dorința paternă de a avea un fiu puternic cu utopia comunistă: „Să pună şi el mâna să mănânce. Să pună niscai carne pe el. Să iasă ceva din el. Pentru că nu ne putem permite să cultivăm asemenea exemplare. Noi trebuie să fim un exemplu. Un model pentru ceilalți. Cum să-şi găsească locul o conştiință nouă într-un trup pricăjit, numai piele şi oase." (Banciu 2019, 169-170) - în timp ce fiica este exceptată de la aceste şicane, pe motiv că: „La fete e altceva. Cine îşi bate capul cu ele. Au vrut egalitate. $\mathrm{O}$ să le iasă pe nas. Cu fetele e altceva. Conform prevederilor, ele sunt imprevizibile." (Banciu 2019, 168) Când fiul trişează, urcându-se pe cântar cu buzunarele îngreunate de pietre, tatăl îl alungă de acasă, realizând a doua ruptură tată-fiu din familie. Artur petrece mai multe luni la țară, la bunica paternă, unde află povestea trădării bunicului Pătru de către propriul fiu. Pe când avea vreo douăzeci de ani, tatăl lui Artur şi-a turnat la miliție tatăl, țăran chiabur care se solidarizase cu mişcarea de rezistență din munți.

Tema delațiunii - fundamentală în înțelegerea mecanismelor totalitare - se îngemănează cu cea a distorsiunii involuntare a realității prin cuvânt, temă recurentă în reflecțiile metatextuale ale jurnalistului de investigație obsedat de obiectivitate. Fricile, micile animozităţi şi interesele mărunte ale oamenilor sunt exploatate de ofițerii Securității pentru a construi din „Cuvinte. Depoziții” (Banciu 2019, 176) o realitate conform cu propriile scopuri. Astfel, din declarațiile disparate ale doamnei Rozica, vecina inconștientă de răul pe care-l face vorbind, colonelul Axente fabrică motive de arestare a lui Maxim şi a Mariei-Maria. Alături de astfel de situații ce expun laşitatea şi conformismul oamenilor de rând, discuțiile de după revoluție contribuie la căderea în derizoriu a noțiunii de erou. Deconstrucția acesteia e desăvârşită irevocabil din perspectiva unui copil:

Măi copii. Ce înțelegem noi prin eroii patriei? Aşa întrebase învăţătoarea. Fosta tovarăşa-învățătoare. [...]

Patria de astăzi nu este patria de ieri. Şi nici voi eroii ei. Noi avem o țară plină de eroi. Spusese copilul. Şi două patrii. Patria de ieri. Şi patria de azi. Eroii de ieri nu sunt cei ai patriei de azi. Dar sunt eroi. Vor fi eroii patriei de ieri eroii patriei de mâine?

Mă doare capul, spusese învățătoarea. Cine vorbeşte din tine, copile?

Asta m-a întrebat, mamă! Îi spusese copilul Mariei-Maria.

(Banciu 2019, 180-181)

Similarităţile dintre anchetele Securității şi investigația jurnalistică inițiată de Radu Iosif - manifeste la nivel de metodă, în ciuda scopurilor radical diferite - au fost observate de Carmen Muşat, prefațatoarea ediției româneşti (Banciu 2019, 6), şi evidențiază un motiv central al cărții: 
(in)capacitatea limbajului de a reda fidel realitatea şi responsabilitatea autorului ce se străduieşte s-o reconstituie. Într-unul dintre pasajele autoreferențiale, în care naratorul încearcă să se definească pe sine, se concentrează tocmai dificultățile, luminile şi umbrele efortului de a fixa faptele istorice şi trăirile protagoniştilor într-un text coerent:

Eu, Radu Iosif, Cel care trage cu urechea. Colecționarul. Ascultătorul. Cuegătorul. Observatorul. Indiscretul. [...] Vreau să ştiu. Ce a fost. Ce n-a fost. Cum a fost. Cine a fost ce. Cine ce e. Şi dacă mai e. vreau să aflu adevărul. Vreau să aflu dacă există adevăr. Vreau să aflu câte fețe are adevărul. Îmi e ruşine şi nu mă ruşinez deloc. Voi scrie. Pagini întregi voi umple. Voi spicui. Voi colecționa cuvinte. Cuvinte rostite în aer. Făcute să se dizolve în eter. [...] colecţionez. Le adun. Le înregistrez. Îndosariez. Le dau viață. O altă viață. O viață veșnică. Eu sunt păstrătorul. Sunt. Nu știu cine sunt. Sunt mai mult decât Radu Iosif. Oare. Există Radu Iosif. Puterea mea e nemărginită. Eu fac efemerul etern.

Vreau să ştiu. Să am o privire de ansamblu. O vedere obiectivă. Eu nu am participat. [...] Din toată strădania mea de a pune în ordine fragmentele. Fragmentele celorlalți. Succesivele lor puncte de vedere. Punctele lor de vedere diferite. Din strădania mea de a obiectiva lipseşte părerea mea subiectivă. (Banciu 2019, 40-41)

$O$ țară plină de eroi se distinge prin mărcile stilistice inconfundabile ale autoarei: ritm rapid, susținut de fraze scurte, nervoase, întrepătrunse de pasaje lirice și secvențe suprarealiste, cum ar fi imaginea recurentă a lui Artur refugiat într-un copac - „un fluture steril. Pe care nu-l visează nicio floare. Un fluture care visează să fie pasăre" (Banciu 2019, 240) - refuzând cu îndârjire să se confrunte cu dezamăgirile lumii de după revoluție.

\section{Dana Ranga}

Cariera literară a Danei Ranga urmează un parcurs similar ce include debutul în limba maternă şi emigrarea în spațiul german la o vârstă adultă. Spre deosebire de ceilalți scriitori discutați aici, Dana Ranga are o dublă identitate artistică, în care literatura şi regia de film au o pondere egală. Născută la Bucureşti în 1964, dintr-un tată român şi o mamă provenită din R.D.G., a studiat medicina la UMF „Carol Davila” şi a părăsit țara în 1987. Stabilită la Berlin, Ranga a urmat studii de semiotică, istoria artei şi teoria filmului la Universitatea Liberă din Berlin. În anii 90 a publicat sporadic poezie şi traduceri în reviste literare germane şi internaţionale şi a debutat în $1997 \mathrm{cu}$ filmul documentar East Side Story, premiat în 1998 la Festivalul de Filme Documentare de la Marsilia. După acest prim succes cinematografic în care este vorba despre specificul filmelor muzicale în țările din blocul sovietic, urmează o serie de trei filme documentare dedicate cosmonauticii - Story (2003)42,

42 Premiat la Marsilia (2003), Leipzig (2003) şi Houston (2004). 
despre astronautul american Story Musgrave, Cosmonaut Polyakov (2007)43 şi I Am in Space (2012), avându-l ca protagonist pe cosmonautul francez Jean-François Clervoy - şi un film despre moarte şi rituri funerare în mediul rural românesc: Oh, Adam (2009). De asemenea, Dana Ranga este autoarea a două piese radiofonice, Das Auge der Supernova 44 (2002), Herz, Kopf, Zahl45 (2005), ambele difuzate de către postul naţional german WDR.

Debutul editorial al poetei Dana Ranga a avut loc în limba română, cu volumul Stop - din pauzele lui Sisif, publicat în 2005 la editura Limes din Cluj-Napoca. Prima carte de versuri în limba germană, Wasserbuch 46 (2011) a adus-o pe autoare în prim planul peisajului literar german, fiind distinsă, trei ani mai târziu, cu premiul de promovare Adelbert von Chamisso. Tot la Suhrkamp a apărut şi a doua carte, intitulată Hauthaus47 (2016), un al treilea volum de poezii Cosmos! fiind în curs de apariție la editura Matthes \& Seitz din Berlin.

În tematica dominantă a liricii Danei Ranga, Rogobete (2018, 263) identifică motivul imponderabilității ca sugestie a detaşării de o identitate stabilă, a ne-fixării într-o matrice culturală şi a unei perpetue pendulări între limbi şi culturi. Într-adevăr, Ranga admite că pentru ea toate cele trei limbi în care poate scrie literatură (germana maternă, româna paternă şi engleza învățată în copilărie) sunt mijloace de expresie echivalente (Dotzauer 2014, 12): „Ich liebe es, die Sprachen zu wechseln, denn das aktiviert mein Gehirn. So kann ich überhaupt denken."48 Fără să-şi sprijine ipoteza pe indicii textuale sau pe vreo afirmație a autoarei, criticul Gregor Dotzauer, membru în juriul Chamisso, îi atestă acesteia influențe din limba română: „Dana Rangas deutsche Texte haben etwas von der Bildhaftigkeit des Rumänischen angenommen: eine Anschaulichkeit, die von den surrealistischen Traditionen, die sie verehrt, noch verstärkt wird. Auch die Lust am gefundenen und fast wie eine Trophäe ausgestellten Wort gehört dazu."49

\footnotetext{
43 Filmul dedicat cosmonautului rus Valeri Polyakov, deținătorul recordului mondial de şedere continuă în spațiu, a obținut premiul festivalului É Tudo Verdade din São Paulo, Brazilia, în anul 2008.

44 Ochiul Supernovei.

45 Inimă, cap, pajură.

${ }^{46}$ Cartea apelor.

47 Casa de piele.

48 Dana Ranga, cit. de G. Dotzauer în Ibid., p. 13. „Ador să schimb limbile fiindcă asta îmi activează creierul. Doar aşa pot gândi."

49 Ibid., p. 12; „Textele germane ale Danei Ranga au preluat ceva din imageria bogată a limbii române: o forță de sugestie potențată de tradițiile suprarealiste pe care ea le venerează. Tot aici se încadrează şi voluptatea cuvântului găsit şi expus aproape ca un trofeu."
} 
Cele două volume apărute la Suhrkamp ne dezvăluie un univers poetic construit în jurul unor constante tematice - spațiile nevăzute, răsturnarea perspectivei antropocentrice şi a relației text- referent - şi susținut de procedee postmoderniste: amestecul de genuri (lirism cu inserții epice şi teoretice), trimiterile livreşti, ludicul, estetizarea realului. Poemele din Wasserbuch imaginează lumea terestră văzută din adâncul apelor, filtrată prin organele de simț ale viețuitoarelor ce populează oceanul planetar, ca o provocare lansată supremației umane. Cuvinteletrofeu, cum ar fi denumirile latineşti ale ființelor marine prezente aproape în fiecare poem, actualizează topos-ul postmodern al limbajului poetic autosuficient. Un scurt poem intitulat Wasser teoretizează importanța elementului acvatic într-un nou context non-antropocentric:

Sie atmen mich ein, ihre Lieder durchziehen mich; ihn, den Einsamsten, trage ich. Das Messer wählt nicht zwischen hell oder dunkel, ein Versteck bleibt mir verwehrt. Hinter dem Spiegel und auf dem Grund, was bin ich? Sie sagen, ich sei nur ein Teil von allem, nur ein Aspekt.50

În timp ce Cosmos! reia tema astronauticii, volumul anterior, Hauthaus, se concentrează asupra microcosmosului, extrăgând din misterele anatomiei şi fiziologiei umane acel rest inefabil de poezie, inaccesibil ştiinței pozitive.

\section{Dana Grigorcea}

În cazul Danei Grigorcea, ancorarea în spațiul românesc e evidentă la nivel tematic, iar biografia autoarei urmează tiparul clasic al literaturii migrației: stabilirea în spațiul germanofon şi abandonarea limbii materne în favoarea germanei ca limbă de expresie literară. Născută în 1979 la Bucureşti, Dana Grigorcea a urmat şcoala germană din Bucureşti şi a debutat în paginile revistei România Literară cu impresii de călătorie din Israel. Aceste prime încercări literare au fost salutate cu entuziasm de critici şi autori consacrați, printre care Constantin Țoiu, care conchidea profetic: „Ne aflăm, cert, înaintea unei autentice prozatoare, al cărei debut, vertiginos (18 ani), vesteşte fără îndoială o personalitate." ${ }^{51}$ După studii de germanistică şi neerlandistică la Facultatea de Limbi şi Literaturi Străine a Universității din Bucureşti, Grigorcea a plecat cu o bursă în Belgia, a studiat regie de film şi teatru la Bruxelles, iar în 2004 a absolvit

50 Dana Ranga: Wasserbuch. Suhrkamp, Berlin 2011, p. 16. Ei mă respiră, cântecele lor mă străbat; pe el, cel mai singur, îl port. Cuțitul nu alege între lumină şi întuneric, nimeni nu-mi dă adăpost. În spatele oglinzii şi în adânc, cine sunt? Ei spun că n-aş fi decât o parte din întreg, doar un aspect.

51 https://webcache.googleusercontent.com/search?q=cache:SNbbmmK3LYoJ:https: //arhiva.romlit.ro/index.pl/cltorie_n_israel\%3FmakePrintable\%3D1+\&cd=7\&hl=ro\&c $\mathrm{t}=\mathrm{clnk} \& \mathrm{gl}=\mathrm{ro}(30.07 .2020)$. 
un master de jurnalism la Universitatea Danubiană din Krems. După aceea, a lucrat pentru diverse ziare şi canale mass-media - redactor la cotidianul Kurier din Viena, la postul de radio Deutsche Welle din Bonn şi la televiziunea Arte din Strassbourg - şi a predat cursuri de film la Şcoala Superioară de Arte din Zürich. Din 2007, Dana Grigorcea trăieşte la Zürich împreună cu soțul ei, scriitorul Perikles Monioudis, și cu cei doi copii. Împreună cu Monioudis, coordonează editura şi blogul de literatură Telegramme. Grigorcea a debutat în 2011 cu romanul Baba Rada. Das Leben ist vergänglich wie die Kopfhaare $5^{2}$ (Baba Rada. Viața-i trecătoare ca firele de păr), pentru care a primit premiul elvețian Literaturperle şi o distincție de onoare a oraşului Zürich. În 2015 apare romanul Das primäre Gefühl der Schuldlosigkeit (Dörlemann, Zürich, reeditat în 2017 la Ullstein, Berlin), cu care autoarea a participat la concursul Ingeborg Bachmann de la Klagenfurt, în cadrul căruia a obținut premiul 3sat. Romanul care s-a bucurat de cronici foarte bune în spațiul german şi a fost nominalizat pentru Schweizer Buchpreis a fost tradus în engleză, română, italiană, bulgară şi neerlandeză. Ediția românească, în traducerea Norei Iuga şi a lui Radu-Mihai Alexe, a apărut la Humanitas în 2016, sub titlul Sentimentul primar al nevinovăţiei. Nuvela Die Dame mit dem maghrebinischen Hündchen (Dörlemann, Zürich 2018) (Doamna cu cățelul magrebin) a fost tradusă în albaneză, franceză şi slovacă. Pe lângă aceste cărți de proză, Grigorcea a mai publicat literatură pentru copii (Mond aus!, 2016, Der Nase nach, 2018, Einmal Haare Schneiden, bitte, 2018, Die Namen der Blumen, 2019)53 o antologie de editoriale scrise pentru revista Operei din Zürich (Frau Mani auf dem Nachhauseweg, 2018)54 şi un eseu despre bine şi frumos (Über Empathie. Macht uns die Kunst zu besseren Menschen?)55.

În romanul de debut, Dana Grigorcea reuşeşte să creioneze un tablou foarte puternic al lumii aspre şi arhaice, pline de credințe şi obicieuri exotice, a Deltei Dunării, pe fundalul căreia se desfăşoară o acțiune palpitantă, cu accente picareşti, relatată la persoana întâi de însăşi protagonista ei, Baba Rada, o bătrână hâtră şi vicleană, care primeşte în casă un terorist scăpat dintr-o închisoare americană din Tulcea, ascunde urmele unor crime şi țese cu tot atâta îndemânare intrigi în propriul folos şi o rețea întreagă de poveşti incredibile.

Sentimentul primar al nevinovăției este, în primul rând, un roman al Bucureştiului, în care atmosfera oraşului e surprinsă foarte nuanțat, cu fațetele ei multiple, sociale şi culturale, şi pe mai multe planuri temporale,

\footnotetext{
52 Publicat inițial la KaMeRu Verlag şi reeditat în 2015 la Dörlemann, Zürich.

53 Stingeți luna!; După nas; Un tuns, vă rog; Numele florilor.

54 Doamna Mani în drum spre casă.

55 Despre empatie. Ne face arta mai buni?
} 
de la ultimii ani ai dictaturii lui Ceauşescu până în primul deceniu al secolului 21. Vocea naratoarei, o tânără angajată a unei bănci, ne poartă prin diferite colțuri ale oraşului, descoperind poveşti de viață din mai multe generații şi straturi de istorie culturală a Bucureştiului. După cum apreciază cronicarul prestigioasei publicații Neue Zürcher Zeitung, romanul conține toate ingredientele literaturii bune: umor, tragedie, poezie, melancolie, suferință, iubire ${ }^{5}$. Victoria, întoarsă de curând în oraşul natal din Elveția, unde îşi construise o carieră în domeniul bancar, devine martora unui jaf armat la locul său de muncă, somptuoasa Casă de Economii şi Consemnaţiuni de pe Calea Victoriei. Primul paragraf al romanului promite, prin imaginea provocator-ironică a fotografiei de epocă, o călătorie anecdotică în trecutul capitalei:

O străfulgerare metalică, anunțând furtuna, şterge relieful oraşului şi-l transformă într-un decor pictat, asemănător celui din studioul foto Diamandi, unde mondenei mele bunici, prima bucureşteancă pozată într-o fustă scurtă, i se făcuse la cerere acea fotografie scandaloasă la brațul bunicului, care, cu pălărie şi baston de gangster, se foieşte nerăbdător şi apare estompat în partea laterală a imaginii. (Grigorcea 2016, 7)

Următoarele câteva pagini schimbă brusc registrul, îndreptând aşteptările cititorului către genul polițist. Cartea construieşte cu abilitate suspansul, oferind inițial şi o pistă falsă, demontată deja în capitolul următor. Ne dăm seama, astfel, curând că jaful nu este decât un pretext care îi facilitează naratoarei incursiuni în propriul trecut şi în istoria locurilor natale. În urma acestui incident, angajatorul îi recomandă Victoriei concediu şi şedințe de psihoterapie. Naratoarea foloseşte prilejul pentru a explora locurile copilăriei şi ale adolescenței şi de a rememora întâmplări şi oameni care au marcat-o, realizând totodată o radiografie a propriei generațiii, care a copilărit în comunism şi s-a format intelectual şi profesional în primii ani de după căderea lui Ceauşescu. În pasaje formulate la prezent, Victoria îşi descrie periplul prin Bucureşti, şedințele de psihoterapie la doamna Miclescu, veche cunoştință din copilăria petrecută în cartierul Cotroceni şi mamă a lui Dinu, fostul iubit al Victoriei, plimbările lungi alături de Flavian, noul iubit, şi întâlnirile cu prieteni. Urmând fluxul asociativ al memoriei, romanul adună laolaltă fragmente din trecutul mai îndepărtat şi mai recent al Bucureştiului. Nume de locuri şi oameni, uşor recognoscibile pentru cei familiarizați cu istoria recentă a României, se regăsesc într-un mozaic de întâmplări reale şi fictive plasate pe două paliere diferite ale trecutului: copilăria

$5^{6}$ «Hier kommt alles zusammen, was gute Literatur ausmacht: Witz, Komik, Tragödie, Poesie, Melancholie, Trauer, Elend, Liebe.» Roman Bucheli: Furioses Finale. În: Neue Zürcher Zeitung, 4.07.2015. https://www.nzz.ch/ feuilleton/buecher/furioses-finale1.18574401? reduced=true (30.07.2020) 
naratoarei, în ultimii ani ai regimului Ceauşescu, şi adolescența ei, în prima jumătate a anilor 90. De la structura micro-socială a străzilor dintre Operă, Biserica Elefterie şi Parcul Arenele Naționale (fost Progresul), cu probleme specifice anilor 80 - filme occidentale văzute pe şest la televiziunea bulgară, fascinația vecinilor pentru unicul deținător de televizor color de pe stradă, remaierea ciorapilor, prezența ominoasă a securistului de cartier, avorturile ilegale - şi până la concertul lui Michael Jackson de pe Stadionul Național în 1992, romanul creează o frescă a lumii bucureştene din ultimele patru decenii. În pasajele redactate la timpul trecut, vocea Victoriei împrumută ceva din acel „sentiment primar al nevinovăției”, invocat în capitolul doi al romanului ca percepție a realității în comunism: încapsulare voită într-o naivitate de copil ce ignoră dimensiunile grave ale întâmplărilor la care asistă.

După cum mărturiseşte într-un interviu, Dana Grigorcea e preocupată de trecutul recent al României şi de reflectarea lui în viețile oamenilor care l-au trăit, iar limba germană îi oferă detaşarea necesară pentru a scrie despre asta57.

\section{Alexandru Bulucz}

În fine, cel mai tânăr reprezentant al literaturii imigranților de origine română în spațiul german şi-a petrecut doar copilăria în România şi, asemenea lui Florescu şi Veteranyi, scrie exclusiv în germană, problematizându-şi totodată înrădăcinarea în limba şi cultura română. Alexandru Bulucz s-a născut în 1987 la Alba Iulia, unde a trăit până la 13 ani. A studiat germanistica și literatura comparată la Universitatea Goethe din Frankfurt am Main. S-a afirmat încă din perioada studiilor ca poet, traducător 58 , critic literar şi editor59. În prezent locuieşte la Berlin, unde editează revista online Faust-Kultur.

Bulucz a debutat în $2016 \mathrm{cu}$ volumul de versuri Aus sein auf uns, apărut la Lyrikedition 2000 în München. Cartea a fost apreciată drept unul dintre cele mai bune debuturi lirice ale anului şi autorul a primit, împreună cu alți trei poeți, o bursă la Haus der Poesie din Berlin. În 2020 i-a apărut a doua carte de poezie, was die Petersilie über die Seele weiß, la Schöffling \& Co., în Frankfurt am Main. În acest volum au fost incluse şi poezii publicate anterior, pentru care autorul a fost distins cu premiul Wolfgang Weyrauch în 2019.

57 https://oe1.orf.at/artikel/418121/Das-primaere-Gefuehl-der-Schuldlosigkeit (12.07.2020)

$5^{8}$ A tradus, printre altele, Le partage des voix de Jean-Luc Nancy şi Vitralii de Alexandru Vona.

59 În 2015 a fondat, la editura Edition Faust, colecţia de dialoguri filosofice Einsichten im Dialog, pe care o coordonează şi în prezent. 
Sub titlul enigmatic was die Petersilie über die Seele weiß (ce ştie pătrunjelul despre suflet) sunt adunate poeme ce articulează teme majore ale literaturii universale - conştiința morții, compasiunea şi ieşirea din sine în întâmpinarea celuilalt, capacitatea limbajului de a transporta emoții autentice - pe care autorul şi le apropriază printr-o ingenioasă punere în relație, integrându-le într-o țesătură strălucitoare de referințe livreşti, jocuri de cuvinte, imagini frapante, nuclee epice şi sentințe aforistice. Poeziile, grupate în zece capitole - precedate de un poem introductiv intitulat Reader's Digest şi încheiate de o postfață a autorului -, sunt scrise preponderent în vers lung şi liber şi coagulate în jurul unor motive recurente: trupul şi procesele lui fiziologice, lumina, rugăciunea şi ritualul ascetic, durerea şi memoria. Deşi nu apelează la forme fixe, poezia lui Bulucz are o muzicalitate interioară nutrită din aliterații şi alți tropi eufonici. Dincolo de figurile fonetice care ritmează textul, poeziile din acest volum dezvăluie creativitatea lingvistică a poetului care se joacă cu limbajul pe urmele lui Heidegger, inventează cuvinte exploatând posibilitățile limbii germane şi face calambururi pe seama unor nume şi expresii cunoscute. Intorsăturile ludice - micile surprize bazate pe polisemie sau paronimie, care creează deliberat confuzie pentru a descoperi apoi cititorului corespondențe etimologice uitate sau alte apropieri nebănuite între cuvinte - produc un efect de suspans inedit pentru genul liric. Această activare a cititorului prin jocuri de limbaj şi prin trimiteri intertextuale, alături de o anumită propensiune narativă, transformă poemele într-o lectură incitantă. Ironia postmodernă, autoreflexivă şi saturată de aluzii culturale, este de asemenea o constantă a liricii lui Bulucz. Însuşi poemul introductiv deschide - prin alăturarea dintre digestie şi diegeză: „digestion statt diegese. Schreiben sei Verdauungsstunde, / Darmkontrakt.” (p. 11)60 - un spațiu foarte generos al iradierilor semantice, de la antica opoziție dintre epos şi vorbire directă până la recuperarea oralității în postmodernitate şi teoriile contemporane despre scriitură şi corp, anticipând totodată teme importante din volum. Dedicația către Paul-Henri Campbell ${ }^{61}$, poet bilingv de origine americană, cu studii la Frankfurt am Main, introduce încă un motiv esențial în lirica lui Alexandru Bulucz - abaterea de la normativitate - şi realizează joncțiunea cu un pasaj-cheie din postfață. După ce întreprinde o întreagă arheologie culturală a termenului „Petersilie” - de la superstițiile germanice şi până

6o Digestie în loc de diegeză. Scrisul ar fi momentul mistuirii. / Contracție intestinală. ${ }^{61}$ Preocupat de problematica dizabilității, Campbell a creat termenul salutonormativity (după modelul conceptului heteronormativity al lui Judith Butler) care sugerează că discursurile dominante în societate privesc lumea din perspectiva omului sănătos. Prin urmare, poezia sa caută să creeze un limbaj apt să exprime „fragilitatea ca agent al sinelui”. https://elevenelevenjournal. com/2016/12/07/interview-with-paul-henricampbell/ (2.08.2020). 
la întâmplările tragice din 1937 relatate de Hubert Fichte ${ }^{62}$ - plasând astfel planta în context tanatic, Bulucz conchide cu privire la propria artă poetică: „So ist auch das dem Leben mit der Endlichkeit abgerungene Schreiben ein Schreiben mit dem eigenen aphasischen Dialekt, ein Schreiben mit Patholekt, ein Leiden am Sich-nicht-normgerechtartikulieren-können.” (p. 109) ${ }^{6} 3$ În prelungirea directă a acestui pasaj despre suferință şi afazie, Bulucz deplânge pierderea accesului la limba română ca pe atrofierea unui organ: „Zu schmerzlich ist es zudem, mitansehen $\mathrm{zu}$ müssen, wie mein Rumänisch immer mehr außer Gebrauch gerät und in mir ausstirbt."64 (p. 109).

Volumul prilejuieşte, dincolo de bogatele rețele de semnificație augmentate de referințe livreşti ce necesită descifrare atentă, şi o interesantă lectură interculturală, deoarece Bulucz îşi lasă poezia impregnată de fragmente din propria istorie individuală şi din geografia locurilor de baştină. În special capitolul Stundenholz (Toaca) se bazează pe asemenea trimiteri la realități româneşti. În poemul cu acelaşi titlu - ce preia elemente din limbajul liturgic, filonul religios fiind, de altfel, foarte important în întreg volumul - există o imagine frapantă care evocă cu ironie delicată sacrul ascuns în profan: „Ahnt Ihr, Rose, was ich glaube? Dass die rumänischen Mütter / ihre Söhne zu Mönchen erziehen. Früh schon zeigen sie ihnen, / wie salata de vinete gemacht wird. Mit dem aus der Buche / geschnitzten Äxtlein klöppelt der kleine Mönch das Fruchtfleisch / der gegrillten Aubergine klein auf dem Brett aus Stundenholz. / Er lernt die Schlagtechnik u. erste freie Rhythmen für die toaca. / So also betet er u. weiß es nicht."65 (p. 35) Pe lângă primul strat de semnificare, cu trimitere evidentă la mânăstirile ortodoxe, poemul

\footnotetext{
${ }^{62}$ Celebrul masacre del perejil, ordonat în 1937 de preşedintele Republicii Dominicane, Rafael Trujillo, împotriva imigranților de origine haitiană, este pus de Hubert Fichte în relație cu pasajul biblic despre războiul dintre efraimiți şi galaadiți (Judecători XII, 5-6), şi capătă valoare paradigmatică în materie de discriminare etnică. Aşa cum efraimiții care pronunțau „Sibolet” în loc de „Şibolet” erau astfel descoperiți şi ucişi, poliția lui Trujillo îi punea pe muncitorii bănuiți a fi haitieni să rostească „perejil” (cuvântul spaniol pentru pătrunjel). Pornind de la premiza că haitienii nu-l pot pronunța pe „r”, cei care spuneau „pelejil” erau asasinați. Cf. Hubert Fichte: Petersilie. Fischer Verlag, Frankfurt am Main 1984, p. 5 .

63 Aşa este şi scrisul smuls vieții conştiente de finitudinea ei, un scris în propriul dialect afazic, un scris în patolect, o suferință provocată de imposibilitatea de te exprima conform normelor.

64 În plus, e foarte dureros să văd cum româna mea iese tot mai mult din uz şi moare în mine.

65 Oare ştiți, Roza, ce cred? Că mamele românce / îşi cresc fiii să fie călugări. De mici le arată / cum se face salata de vinete. Cu toporişca / de fag micuțul călugăr toacă mărunt pulpa / de vânătă coaptă pe fundul de lemn. / Învață tehnica de percuție şi primele ritmuri libere pentru toacă. / Astfel se roagă fără să ştie.
} 
conține o aluzie încriptată la Paul Celan, un autor extrem de prețuit de Bulucz. În afară de menționarea unor elemente geografice sugestive „Wir flogen Karpatenhügel entlang, / über den südlichen Bug. Den bukowinischen Fragen, wo Heimat / beginne, Erinnerung ende, glaub“ ich die Fragezeichen.”66 (p. 35) - însuşi cuvântul „Stundenholz” se dovedeşte a fi o referință intertextuală, dacă ne gândim la poezia lui Celan Eine Hand, unde se poate citi versul: „Der Tisch, aus Stundenholz, mit dem Reisgericht und dem Wein." (Masa, din lemn de toacă, cu mâncarea de orez şi vinul). Într-o dezbatere radiofonică despre Celan, la care au participat mai mulți poeți germani, Bulucz îşi mărturiseşte pasiunea pentru poetul bucovinean, începută încă din timpul studiilor şi înlesnită de profesorul său Werner Hamacher, elev al lui Peter Szondi, unul dintre primii interpreți ai lui Celan67. Citând, alături de poezii ale lui Celan, un fragment din propria poezie Stundenholz, Bulucz se situează în tradiția acestuia, pledând - în contextul celebrei controverse dintre Celan şi Adorno, legate de estetizarea suferinței - pentru reabilitarea patosului în lirica contemporană68.

În postfața intitulată „Die angelehnte Tür des Gedichts” (Uşa întredeschisă a poeziei, pp. 107-111), poetul îşi expune crezul artistic inspirat de imaginea uşilor deschise din Crimă şi pedeapsă de Dostoievski, dar şi de ideea de dialog prezentă la Celan: literatura ca disponibilitate a deschiderii față de celălalt, ca sensibilizare față de alteritate. În lumina acestui imperativ etic trebuie înțeleasă poetica antihermetică a lui Bulucz, impulsul de a se face înțeles, de a construi punți ale dialogului într-o lume scindată (cf. p. 110).

În persoana lui Alexandru Bulucz lirica germană contemporană a câştigat un poeta doctus, cu o voce distinctă, racordată la canonul literar german şi la tradiția umanistă cu marile ei teme universale - secularizare, suferință, compasiune - şi părtaş totodată la o umanitate particulară, modelată de diferența etno-culturală. Într-un interviu, autorul mărturiseşte că tema sa fundamentală - anthropos-ul în toate dimensiunile sale - este un „Leid-Motiv" 69 profund ancorat în biografia individuală, mai exact în cutumele şi reflexele comportamentale la care a fost expus în primii treiseprezece ani petrecuți în România70 .

\footnotetext{
${ }^{66}$ Am zburat de-a lungul Carpaților / peste Bugul de sud. Întrebărilor bucovinene, unde începe / patria şi unde se termină amintirea, le iau în serios semnele de întrebare.

67 Paul Celan, Dichter, emisiune de Norbert Hummelt, difuzată de SWR la 21.04.2020; https://www.swr.de/swr2/literatur/paul-celan-dichter-swr2-lesenswert-feature-202004-21-100.pdf (3.08.2020)

68 Ibid.

69 Joc de cuvinte; „Leid” = suferință.

70 Cf. Entre nous, Alexandru Bulucz! https://www.neue-telegramme.ch/10021226 /metier-des-menschen (23.07.2020).
} 


\section{Bibilografie}

Banciu, Carmen-Francesca. (1984). Manual de întrebări. Bucureşti: Editura Cartea Românească.

Banciu, Carmen-Francesca. (1992, 2015). Fenster in Flammen. Trad. Rolf Bossert şi Ernest Wichner. Berlin: Rotbuch Verlag; reeditat: Berlin: PalmArtPress.

Banciu, Carmen-Francesca. (1995, 2017). Filuteks Handbuch der Fragen. Trad. Georg Aescht. Berlin: Rotbuch Verlag; reeditat: Berlin: PalmArtPress.

Banciu, Carmen-Francesca. (1998). O zi fără preşedinte. Bucureşti: Editura Fundației Culturale Române.

Banciu, Carmen-Francesca. (1998, 2009). Vaterflucht. Berlin: Volk und Welt; reeditat: Berlin: Rotbuch Verlag.

Banciu, Carmen-Francesca. (2000, 2019). Ein Land voller Helden. Berlin: Ullstein; reeditat: Berlin: PalmArtPress.

Banciu, Carmen-Francesca. (2002, 2007). Berlin ist mein Paris, Geschichten aus der Hauptstadt. Berlin: Ullstein; reeditat: Berlin: Rotbuch Verlag.

Banciu, Carmen-Francesca. (2007). Das Lied der traurigen Mutter. Berlin: Rotbuch.

Banciu, Carmen-Francesca. (2015). Leichter Wind im Paradies. Berlin: PalmArtPress.

Banciu, Carmen-Francesca. (2018). Lebt wohl, Ihr Genossen und Geliebten! Berlin: PalmArtPress.

Banciu, Carmen-Francesca. (2019). O țară plină de eroi. Trad. Ana Mureşanu, Bucureşti: Editura Tracus Arte.

Bulucz, Alexandru. (2016). Aus sein auf uns. München: Lyrikedition 2000.

Bulucz, Alexandru. (2020). was Petersilie über die Seele weiß. Frankfurt am Main: Schöffling \& Co.

Florescu, Cătălin Dorian. (2001, 2003). Wunderzeit. Zürich: Pendo; reeditat: München: Diana.

Florescu, Cătălin Dorian. (2002). Der kurze Weg nach Hause. Zürich: Pendo.

Florescu, Cătălin Dorian. (2005). Vremea minunilor. Trad. Mariana Bărbulescu, Iaşi: Editura Polirom.

Florescu, Cătălin Dorian. (2006). Drumul scurt spre casă. Trad. Mariana Bărbulescu, Iaşi: Editura Polirom.

Florescu, Cătălin Dorian. (2006, 2009). Der blinde Masseur. Zürich: Pendo; reeditat: München: Piper.

Florescu, Cătălin Dorian. (2007). Maseurul orb. Trad. Mariana Bărbulescu. Iaşi: Editura Polirom.

Florescu, Cătălin Dorian. (2008, 2009). Zaira. München: C.H. Beck; reeditat: München: dtv.

Florescu, Cătălin Dorian. (2010). Zaira. Trad. Marana Bărbulescu, Iaşi: Editura Polirom.

Florescu, Cătălin Dorian. (2011). Jacob beschließt zu lieben. München: Editura C.H.Beck.

Florescu, Cătălin Dorian. (2012). Jacob se hotărăşte să iubească. Trad. Mariana Bărbulescu. Iaşi: Editura Polirom.

Florescu, Cătălin Dorian. (2016). Der Mann, der das Glück bringt. München: Editura C.H.Beck.

Florescu, Cătălin Dorian. (2017). Der Nabel der Welt. München: Editura C.H.Beck.

Florescu, Cătălin Dorian. (2018). Bărbatul care aduce fericirea. Trad. Mariana Bărbulescu, Bucureşti: Editura Humanitas.

Florescu, Cătălin Dorian. (2019). În buricul pământului. Trad. Mariana Bărbulescu, Bucureşti: Humanitas. 
Grigorcea, Dana. (2011, 2015). Baba Rada. Das Leben ist vergänglich wie die Kopfhaare. Zürich: KaMeRu Verlag; reeditat: Zürich: Dörlemann.

Grigorcea, Dana. (2016). Mond aus!. Glarus: Baeschlin.

Grigorcea, Dana. (2016). Sentimentul primar al nevinovăţiei. Trad. Nora Iuga şi RaduMihai Alexe. Bucureşti: Editura Humanitas.

Grigorcea, Dana. (2017). Das primäre Gefühl der Schuldlosigkeit. Roman. Zürich: Dörlemann, 2015; reeditat: Berlin: Ullstein.

Grigorcea, Dana. (2018). Der Nase nach. Glarus: Baeschlin.

Grigorcea, Dana. (2018). Die Dame mit dem maghrebinischen Hündchen. Zürich: Dörlemann.

Grigorcea, Dana. (2018). Einmal Haare Schneiden, bitte. Glarus: Baeschlin.

Grigorcea, Dana. (2018). Frau Mani auf dem Nachhauseweg. Hamburg: Literatur Quickie.

Grigorcea, Dana. (2019). Die Namen der Blumen. Glarus: Baeschlin.

Grigorcea, Dana. (2019). Über Empathie. Macht uns die Kunst zu besseren Menschen? Zürich: Telegramme Verlag.

Ranga, Dana. (2005). Stop - din pauzele lui Sisif. Cluj-Napoca: Editura Limes.

Ranga, Dana. (2011). Wasserbuch. Berlin: Suhrkamp.

Ranga, Dana. (2016). Hauthaus. Berlin: Suhrkamp.

Ranga, Dana. (2020). Cosmos! Berlin: Matthes\&Seitz.

Veteranyi, Aglaja. (1999). Ein Totentanz: Geschenke. Zürich: Edition Peter Petrej.

Veteranyi, Aglaja. (1999, 2001). Warum das Kind in der Polenta kocht. Stuttgart: Deutsche Verlags-Anstalt; reeditat: München: Deutscher Taschenbuch-Verlag.

Veteranyi, Aglaja. (2002). Das Regal der letzten Atemzüge. Stuttgart: Deutsche VerlagsAnstalt.

Veteranyi, Aglaja. (2002). De ce fierbe copilul în mămăligă. Trad. Nora Iuga. Iaşi: Polirom; reeditat: 2003, 2013,2016

Veteranyi, Aglaja. (2003, 2019). Raftul cu ultimele suflări. Trad. Nora Iuga. Iaşi: Editura Polirom.

Veteranyi, Aglaja. (2004, 2012). Vom geräumten Meer, den gemieteten Socken und Frau Butter. Stuttgart: Deutsche Verlags-Anstalt; reeditat: München: Deutscher Taschenbuch-Verlag.

Veteranyi, Aglaja. (2018). Café Papa. Fragmente. Luzern: Der gesunde Menschenversand.

Veteranyi, Aglaja. (2018). Hier Himmel. 30 Postkarten. Luzern: Der gesunde Menschenversand.

Veteranyi, Aglaja. (2018). Wörter statt Möbel. Fundstücke. Luzern: Der gesunde Menschenversand. 


\section{Surse secundare}

Dotzauer, Gregor. (2014). Die Literatur ist meine Wurzel, mein Land, mein Zuhause. În „Chamisso Magazine. Viele Kulturen - eine Sprache”, März 2014, No. 10, p. 12. http:// www.bosch-stiftung.de/content/language1/ downloads/Chamisso_Magazin_10.pdf (27.07.2020).

Entre nous, Alexandru Bulucz! https://www.neue-telegramme.ch/10021226/ metierdes-menschen (23.07.2020)

Fichte, Hubert. (1984). Petersilie. Frankfurt am Main: Fischer Verlag.

Gieser, Laura. (2006). "Heimatlose Weltliteratur? Zum Werk von AglajaVeteranyi”. In: Germanica, 38(2006). URL: http://journals. openedition.org/germanica/409; DOI: https://doi.org/10.4000/ germanica.409 (13.07.2020).

http://levurelitteraire.com/carmen-francesca-banciu-interview-roumain/. (12.07.2020)

https://elevenelevenjournal.com/2016/12/o7/interview-with-paul-henri-campbell/ (2.08.2020).

https://oe1.orf.at/artikel/418121/Das-primaere-Gefuehl-der-Schuldlosigkeit (12.07.2020).

https://webcache.googleusercontent.com/search?q=cache:SNbbmmK3LYoJ:https://a rhiva.romlit.ro/index.pl/cltorie_n_israel\%3FmakePrintable\%3D1+\&cd=7\&hl= ro\&ct $=$ clnk\&gl=ro (30.07.2020).

Interviu cu Ana-Maria Mandra. http://levurelitteraire.com/carmen-francesca-banciuinterview-roumain/ (25.07.2020).

Interviu cu Doina Ioanid: https://www.observatorcultural.ro/articol/ sint-asa-defericit-de-a-avea-romania-ca-pamint-fertil-al-imaginatiei-mele/ (20.07.2020).

Interviu cu Sorin Şerb: https://romania.europalibera.org/a/ 30037310.html (20.07.2020).

Interviucu Codruța Simina: https://pressone.ro/catalin-dorian-florescu-scriitorpojghita-de-civilizatie-este-foarte-subtire-peste-tot-are-fisuri-nu-doar-in-estci-si-in-vest (20.07.2020).

Iuga, Nora. (2012). „Aglaja nu vorbea despre moarte.” Interviu cu Nora Iuga, consemnat de George Chiriac. Dilema Veche, nr. 418, 16-22 februarie 2012, accesibil onlilne, https://dilemaveche.ro/sectiune/carte/articol/ aglaja-nu-vorbea-despre-moarteinterviu-cu-nora-iuga(accesat 12.07.2020).

Negruzzi, Iacob. (2014). Jurnal, trad. de Horst Fassel, Iaşi: Editura Muzeelor Literare.

Paul Celan, Dichter, emisiune de Norbert Hummelt, difuzată de SWR la 21.04.2020; https://www.swr.de/swr2/literatur/paul-celan-dichter-swr2-lesenswertfeature-2020-04-21-100.pdf (3.08.2020)

Rogobete Roxana. (2018). „Scriitori de origine română în spațiul germanofon (C. D. Forescu, A. Veteranyi, D. Ranga, C. M. Florian)”. în Quaestiones Romanicae VI. Canon cultural. Canon literar. Canon lingvistic. Lucrările Colocviului Internațional Comunicare şi cultură în Romània europeană (ediția a VI-a / 1617 iunie 2016). „Jozsef Attila” Tudomanyi Egyetem Kiado Szeged. 